Cursor_Zeitschrift für explorative Theologie

\title{
Digital Theology as \\ Contextual Theology: A \\ Preliminary Reflection
}

Katherine Schmidt

Published on: Nov 06, 2020

DOI: $10.21428 /$ fb61f6aa.db562fe6

License: Creative Commons Attribution 4.0 International License(CC-BY 4.0). 
The president of my college claims that when I met him almost four years ago, I introduced myself as a digital theologian. This is absolutely not true, but he keeps saying it, and saying it publicly, and I'm not about to correct him. The truth is that during my doctoral work and even some days now, I consider myself a systematic theologian who primarily studies digital culture. It never occurred to me to describe myself as a digital theologian because I wasn't even sure what it means. I'm still not entirely sure what it means, but I've come around to the idea of being a digital theologian, which definitely makes more sense when one considers the work of the Centre for Digital Theology at Saint John's College, Durham University.

I had the pleasure of being in Durham in September for the first international conference of the Global Network for Digital Theology. We spent our time together asking about the nature of digital theology, and since then, I have been mulling over the idea of digital theology as contextual theology. This idea comes from the methodological question of whether or not digital theology can stand on its own as something distinct from other kinds of theology, and if so, what its method might be. In what follows, I'd like to give some brief thoughts on digital theology as contextual theology. I will explore the ways in which it seems to reflect the method of existing contextual theologies, as well as the ways in which it may be inappropriate to categorize digital theology in this way.

Stephen Bevans claimed in 1992 that "there is only contextual theology," and that "doing theology contextually is not an option." His book, Models of Contextual Theology, argues that the traditional model of theology as an objective science is untenable, even false, and that to the two loci of Scripture and Tradition, contextual theology adds "present human experience." This seems even more the case in the nearly 30 years since Bevans' work, as the original impulse to bring marginalized voices into the theological conversation has only become more urgent. We can no longer do theology as if it hovers free from geographic, economic, historical, sexual, racial, or national particularities. Theology, as the human reflection on divine revelation, takes as its subject a thing transcendent, but must always do so within the context in which the theologian finds herself. In truth, Bevans doesn't add the third locus of present human experience so much as he wants to acknowledge the role of context in both Scripture and Tradition. Both Scripture and Tradition are mediations that are marked by and subject to the contextual realities of history.

On this point, then, of course digital theology can be understood as contextual, as it takes the digital context as the location from which it engages in theological reflection. But Bevans does overstate his point, and one wonders about the need for delineating contextual theology at all if all theology is contextual. If that's true, why not just call it theology? It seems to me that the assumption of contextual theologies is that the dominant traditions of Christian theology have been beholden to western, white, heteronormative, Anglo and European assumptions, and that by the latter decades of 
the 20th century, we were long overdue to consider that these traditions are not the only or best way to do theology just because they have dominated. Womanist, feminist, black, Asian, and queer theologies, to name just a few, reflect a theological method that takes the lived experiences of marginalized people as the starting point for theological reflection. If this amplification of marginalized voices truly is what separates contextual theology from the rest, we have to ask the question of whether or not digital theology does the same.

At first blush, it appears that digital theology does not in fact represent a theology of the marginalized in the same way as other contextual theologies. Many if not all contextual theologies bring the experiences of violent and oppressive systems to bear on theological questions. North American black theology, for example, sets itself against dominant American white theology, which "has been basically a theology of the white oppressor." - It seeks to recast Christian theology as a theology of liberation, analyzing "the nature of the gospel of Jesus Christ in the light of oppressed blacks." I take Cone's method here as representative of contextual theology in its liberative impulse. Contextual theologies share a commitment to acknowledging context 1) to expose contextual assumptions that have served to exclude marginalized groups, and/or 2) to highlight or draw out contextual particularities and to offer them as important or even primary assumptions for theology. That is, one must consider context not only as means by which to highlight the marginalized but also as a means by which to expose exclusionary assumptions in dominant traditions.

According to Bevans, the "context" of "contextual" is made up of personal/communal experience, culture, social location, and social change. But it seems to me that social change looms larger than the other factors, insofar as the privileging of context is in service to a larger project of something like academic social justice. In designating it as "academic," I do not mean to imply that contextual theologies don't have real, practical effects. Indeed, contextual theologies over the past three decades have had real effects on church practice, social outreach, and more. While I don't want to completely ignore Bevans' typology of contextual theology, I want to suggest that there is an important operative assumption of liberation at work in the very practice of contextualization, and that it is this assumption with which our investigation into digital theology must contend.

It seems disingenuous to argue that digital theology is about the liberation of people or the amplification of marginalized voices in the same way as traditional contextual theologies. After all, the internet is arguably the logical conclusion of the very same systems that often come under scrutiny from contextual theologies: neoliberalism, misogyny, militarism, nationalism, and racism. The internet is not a neutral tool or space; it carries the values of culture within its structures and logics. It seems silly, if not downright disrespectful, to even suggest that digital theology might have the same liberative assumption as contextual theologies. 
There is, however, an analogy to be made for digital theology. I suggest that the digital context is a marginal context for most theologians and pastors. For many of the theologically-interested, it represents an optional social phenomenon, often laden with more antithetical practices and assumptions than not. In saying this, I only want to argue that it is marginal in the sense of almost never enjoying a primary place in theological reflection. In the ten or so years since I began theological work in a digital context, this has certainly become less and less the case, but I think it is true for the most part.

To the extent that academic theology considers digital culture as a font of lived human experience for theological reflection, it does so often as an additional or auxiliary consideration to a theology that hovers free from the digital context. Moreover, my impression is that academic theology rarely if ever considers digital culture as a possible source for new hermeneutical approaches that can further explicate the mysteries of revelation. More often than not, the digital context represents an object of study upon which we place traditional hermeneutical frameworks from extant theological methods, including the contextual. Digital culture becomes merely the logical and amplified extension of other social phenomena - the political, the economic, the gendered, the racial-and thus the digital context is ripe for theologizing, but only to the extent that it receives our assumptions.

Throughout my work, I have attempted to move beyond what I see as the dominant theological trend vis a vis digital culture, namely simply applying theological categories and methods to various aspects of digital technology. By contrast, I present a theological hermeneutic of virtuality, which comes uniquely out of the context of digital culture, and returns naturally to the artifacts and particularities of that culture. But it does so even as it is able to encompass and address itself beyond this one context. In the same way that Black theology only makes sense within the cultural and historical construction of blackness and whiteness, so too does digital theology only make sense within the historical and cultural periods after the permeation of the digital in contemporary society. However, Black theology addresses itself to the entirety of the Christian tradition, rightly assuming that the lived experience of people in a particular place and time does indeed bring to light new insights on the ancient truths of revelation.

To summarize, digital theology cannot claim the same liberative assumption as most contextual theologies. It does, however, express the methodological approach of contextual theology insofar as it asserts the primacy of digital technology for theological work. If by digital theology, we simply mean the application of extant theological categories to the particularities of digital technology, then I would resist categorizing it as contextual. If we mean, however, that theological reflection takes as its starting point the lived experiences of persons, ecclesial and otherwise, in the explicit context of digital platforms, as well as in the social realities that are now undeniably shaped by digital culture, then it seems appropriate to give it this description. 
I'd like to briefly suggest (four) possible assumptions embedded within the method of digital theology. I offer them tentatively, as a preliminary discussion, and look forward to refining them with those present in the coming years.

\section{SOCIAL}

Digital theology assumes that: to the extent that Christian theology considers the social dimension of human life, it cannot consider digital culture as less than primary to theological reflection, in many if not most parts of the world. We must acknowledge here the reality of the digital divide, but even in the most economically oppressive areas of the world, digital culture is re-shaping what it means to be social.

\section{ECCLESIAL}

Digital theology assumes that: to the extent that Christian theology understands the church as subject to historical particularities in its mediation of divine revelation, ecclesiology cannot consider a vision of the church without a substantive consideration of the digital. Given the assumption above re: the social, it follows that ecclesiology in the 21st century is lacking without consideration of the digital. Furthermore, by "substantive," I mean a consideration that takes digital life as a constitutive element in ecclesial community.

\section{ANTHROPOLOGICAL}

Digital theology assumes that: to the extent that Christian theology addresses itself to what it means to be human, even as it explores the deepest questions about the nature of God, it must do so in the context of shifting conceptions of humanity as a result of technology (i.e. AI, transhumanism, etc.). In order to properly address the question of what it means to be human from a theological perspective, all theologians must be aware of and in conversation with the evolution of technology as it affects the most basic aspects of the human body and mind.

\section{HERMENEUTICAL}

Digital theology assumes that: the digital context is not simply (or even necessarily) an object of theological reflection, but a formative context for theologians in the 21st century. As such, it can provide new hermeneutic lenses through which to understand revelation, as well as the realities of human life (especially in digital contexts) in light of revelation. This requires the underlying and thus far difficult assumption that God's grace can indeed be found within the digital context, and that the digital context has an active role to play in the further unfolding of the mystery of God.

I'll conclude here with a brief acknowledgement of a shortcoming: I did not say enough here about the features or constitutive elements of "digital culture" or the "digital context." For me, I focus primarily 
on the digital platforms oriented toward social life, as the relationship of the Church and the social has long been my theological preoccupation. In assumption 3, however, I gesture towards other elements of digital culture like artificial intelligence in order to begin to capture the multitudes of technological materials that may be in the purview of digital theology. In short, I believe that digital theology is contextual theology insofar as it understands the digital context as a dynamic and reciprocal collection of lived human experiences that is not only subject to but also a substantive source of theological reflection.

\section{Footnotes}

1. James H. Cone, A Black Theology of Liberation (New York: Orbis, 2010), $4 . \boxminus$

2. Cone, $5 . \unlhd$ 